\title{
Cheap Signals with Costly Consequences
}

\author{
THE EFFECT OF INTERSTATE RELATIONS ON CIVIL WAR
}

\author{
CLAYTON L. THYNE \\ Department of Political Science \\ University of Iowa
}

\begin{abstract}
This article examines the effect of interstate signals on the probability of civil war onset. Using a bargaining framework, the author argues that costly signals should have no effect on the likelihood that a civil war begins because they allow the government and opposition to peacefully adjust their bargaining positions to avoid the costs of fighting. In contrast, cheap signals can disrupt intrastate negotiations, which makes conflict more likely by increasing the likelihood that one of the competing parties will make excessive demands. This argument is tested using measures for sanctions, troop mobilization, alliances, and trade ties as indicators for costly signals, as well as events data as measures for cheap signals. Results demonstrate that cheap signals strongly affect the probability of civil war onset, while costly signals do not. Cheap signals hostile to the government increase the likelihood of civil war onset, while cheap supportive signals have a pacifying effect.
\end{abstract}

Keywords: civil war; signals; international relations; bargaining theory

T

he terrible consequences of civil wars have driven conflict scholars to better understand their causes, duration, severity, and outcomes. Over the past fifty years, these conflicts have caused more than 16 million deaths and have lasted over six years on average. Civil wars also disrupt society by causing massive flights of refugees, devastating countries' economies, and interrupting social programs (Singer and Small 1994; Collier et al. 2003; Fearon and Laitin 2003). One vein of research examines the effect of external actors on the duration, outcome, and settlements of civil wars (e.g., BalchLindsay and Enterline 2000; Regan 2002; Walter 2002; DeRouen and Sobek 2004). However, few studies have examined the effect of third parties on the onset of civil war. ${ }^{1}$ This gap in the literature is problematic because states do not exist in a vacuum

1. Exceptions include Moore (1995), Sambanis (2001), Cetinyan (2002), Gleditsch and Beardsley (2004), Salehyan and Gleditsch (2006), and Gleditsch (forthcoming).

AUTHOR'S NOTE: I thank Sara McLaughlin-Mitchell, Brian Lai, Kelly M. Kadera, Will H. Moore, and Joseph Young for helpful comments. Earlier versions of this article were presented at the Illinois State Conference for Students of Political Science, Normal, Illinois; the Midwest Political Science Association Annual Conference, Chicago; and the James F. Jakobsen Graduate Forum, Iowa City, Iowa. Replication data can be found at http://jcr.sagepub.com/cgi/content/full/50/6/937/DC1/. 
but are influenced by external actors. This article seeks to fill this hole in the literature by asking the following: how might relations between states affect the likelihood of civil war onset? What type of relations, if any, matter?

\section{FRAMEWORK FOR ANALYSIS}

Many scholars use a bargaining framework to explain the onset of interstate conflict (e.g., Morrow 1989; Kilgour and Zagare 1991; Gartzke 1999; Powell 1999, 2002). According to the bargaining model, states compete over resource allocations and/or policy choices (Reiter 2003, 28). Because war is costly, competing sides will seek to avoid conflict by making demands and/or concessions. They are able to maintain peace if they hold common beliefs about the end result of a future war. Fearon (1995) identifies three factors that increase the likelihood of bargaining failures: disagreement over the likely outcome of war, inability to credibly commit to not fight in the future, and issue indivisibilities.

While the bargaining model has received a great deal of attention in the interstate war literature, few scholars have attempted to extend the same logic to the study of intrastate disputes. ${ }^{2}$ This is puzzling given that the important characteristics of interstate struggles are also present in civil conflicts. At its basic level, the source of conflict in both contexts is a disagreement about what would happen if a war were to begin. The same causal mechanisms identified by Fearon (1995)—incentives to misrepresent, inability to make credible commitments, and issue indivisibilities-are also present in civil conflicts. If the government and the opposition have perfect (or near-perfect) information about the strength, resolve, and demands of the other side, we should expect them to come to an agreement to avoid the costs of fighting. This expectation is captured in Figure 1. In this figure, the solid line represents the bargaining space the two actors are competing over (e.g., territory), with the government's ideal position at the extreme right and the opposition's at the extreme left. Each side prefers to move the status quo toward its ideal point. They also have expectations regarding the future position were a war to break out $\left(\mathrm{G}_{\text {exp }}\right.$ and $\left.\mathrm{O}_{\text {exp }}\right)$, which may be preferable to the status quo. Because war is costly, each will accept a settlement less than its ideal point and less than that which it might expect to achieve through violent means $\left(\mathrm{G}_{\text {acc }}\right.$ and $\left.\mathrm{O}_{\text {acc }}\right)$. In this situation, there is an overlapping "settlement zone" that both actors will accept, resulting in a stable and peaceful equilibrium. This figure represents the situation in the majority of states.

Despite the peaceful predictions of the basic bargaining framework, civil wars happen frequently and with devastating consequences. Examining sources of uncertainty provides a key to understanding why the government and opposition might fail to agree on mutually acceptable bargaining positions. The remainder of this article examines how external actors may be one vehicle by which uncertainty is introduced into intrastate bargaining.

2. Exceptions include Cetinyan (2002), Regan and Aydin (2005), and Werner and Yuen (2005). 


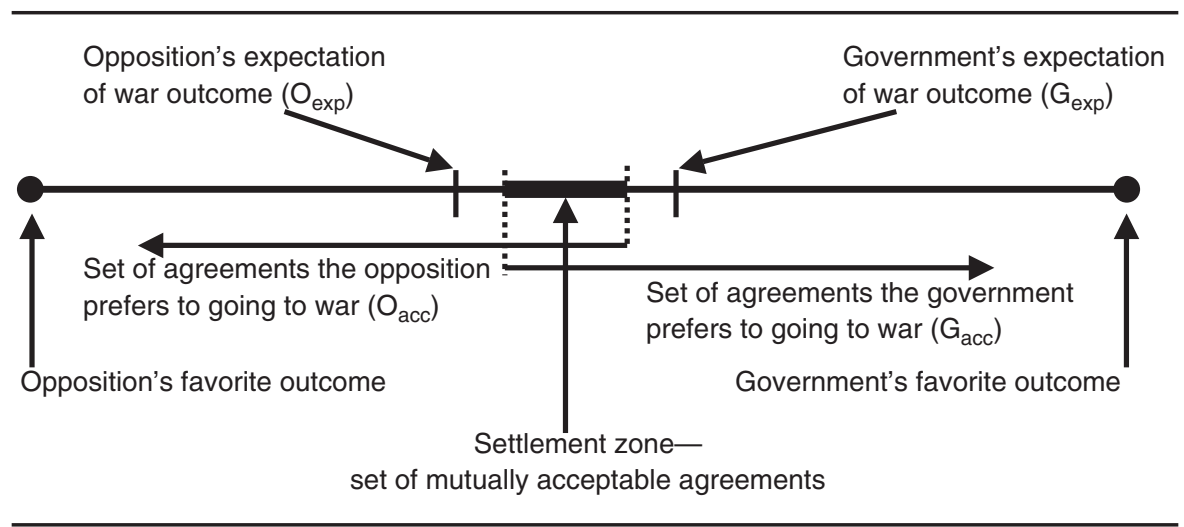

Figure 1: Intrastate Bargaining Positions without Considering Interstate Signals

\section{COSTLY SIGNALS AND INTRASTATE BARGAINING}

Intergovernmental relations affect intrastate bargaining because they signal information about an outside actor's likelihood of aiding either the government or the opposition if a civil war were to begin. While I assume that these signals are received by both parties, we cannot assume that they are sent with the same purpose, nor can we assume that all signals are interpreted by the government and opposition in the same manner. Examining the effect of a variety of signals on intrastate bargaining positions should help us better understand how interstate relations might affect civil war. Scholars studying credibility of signals have noted that the signaling state must suffer some costs for sending the signal if it is to be credible (Morrow 1999, 484). Fearon $(1997,69-70)$ refines this argument, explaining that actors have two choices by which they can send credible signals. The first is to create ex post audience costs for bluffing (usually in the form of public statements), which he refers to as "tying hands." The second is to create financially costly moves, which he refers to as "sunk costs." We can use Fearon's argument to group signals into two categories: costly and cheap. Costly signals are those that come with high levels of "tying hands" and/or "sunk costs." They represent clear and direct positions from an external actor that are costly to establish and maintain. They are transparent and stable over time. Examples of costly supportive signals include military alliances and trade ties. Examples of costly hostile signals include troop mobilizations and economic sanctions. ${ }^{3}$ Each of these is financially costly and transparent. For example, U.S. sanctions on South Africa in 1986 were costly because they forced the United States to find alternative trade partners and transparent because they came after years of public debate and an open discussion in Congress. Likewise, the establishment of trade ties between the United States and Mexico was costly because it forced the United States to develop a trading infrastructure and took decades to progress.

3. The words supportive and hostile in the text refer to relations between governments only. 
Given this definition, what is the expected effect of costly signals on intrastate bargaining? Theory rooted in the economics literature known as rational expectations provides leverage in answering this question. According to McGinnis and Williams (2001, 53), "Rational expectations refers to the aggregate result of private economic actors utilizing relevant information in forming unbiased expectations of the future behavior of the economy as a whole." Actors in competition respond not only to current conditions but also to expectations of future events. Under complete information-where the competing parties have an accurate assessment of the other's preferences, capabilities, and beliefs - the parties should be able to peacefully negotiate a settlement because they can easily predict the outcome of a future conflict. For example, McGinnis and Williams explain that the stability of the superpower rivalry during the cold war was maintained primarily because each state was sufficiently well informed about the capabilities of the other side, making each able to forecast the other's future behavior and adjust its current policies accordingly. Others have used the rational expectations framework to explain interstate trade (Morrow 1999; Li and Sacko 2002), diversionary theory (Fordham 2005), and both interstate and intrastate disputes (Blainey 1988; Moore 1995; Walter 1997; Lake and Rothchild 1998; Gartzke 1999; Wagner 2000; Moore and Lanoue 2003). Like these authors, my argument extends the rational expectations framework beyond economics by applying it to intrastate bargaining.

We should expect costly signals to allow the government and opposition plenty of time to alter their bargaining positions to avoid conflict because they clearly relate information about who would receive aid and the extent of that aid, if a civil war were to begin. In Figure 1, a costly hostile signal should cause both the government $\left(\mathrm{G}_{\mathrm{acc}}\right)$ and the opposition $\left(\mathrm{O}_{\mathrm{acc}}\right)$ to shift their bargaining positions to the left (in favor of the opposition), while a costly supportive signal will shift their bargaining positions to the right (in favor of the government). The net effect of costly signals, therefore, is to adjust the bargaining range of both actors while maintaining the relative distance between acceptable settlement positions. This is the expected result of U.S. sanctions placed on South Africa. Because the position of the United States was signaled in a predictable manner prior to the implementation of sanctions, the final decision came as a shock to no one. This gave the government plenty of time to appease the opposition's demands to prevent an all-out rebellion. ${ }^{4}$ Similarly, the establishment of governmental support in the form of trade ties with Mexico sent a costly signal to the opposition, depressing their predicted outcome of a future civil conflict and thus forcing them to adjust their bargaining position. In both of these cases, the costly interstate relations allowed change within the countries to come slowly and peacefully.

4. In 1990, the National Party Government embarked on a program of radical reform that led to South Africa's first fully democratic election in April 1994. As Manby (1992, 217) notes, "Although sanctions were not the only factor in the South African government's decision to initiate a process of negotiation with the black liberation movements and to repeal the major apartheid legislation, such international economic isolation made it impossible to repress the internal demand for political change indefinitely." 
The logic of this argument is also consistent with claims made elsewhere in the literature. In the deterrence literature, Fearon (1994) and Danilovic (2001) argue that costly signals tell a potential attacker that a defender's protégé is likely to have support if attacked, making it unlikely that an attack will take place. The argument also closely parallels a claim introduced in the civil war literature by Cetinyan (2002), who suggests that expectations for future support during a civil war are endogenous to the initial decision to rebel. Because the costly signals are easy to interpret by both sides, there is no reason to expect a divergence in the mutually acceptable bargaining range. This expectation leads to the first hypothesis:

Hypothesis 1: Costly signals sent from the external actors-whether supportive or hostile-should have little effect on the probability of civil war onset.

\section{CHEAP SIGNALS AND INTRASTATE BARGAINING}

The next step is to examine how cheap signals might affect intrastate bargaining. ${ }^{5}$ Cheap signals include day-to-day communications that are apt to exhibit a high degree of volatility over time. These include statements of condemnation or threats to sanction on the hostile side. President Bush's 2005 State of the Union address openly expresses support for the opposition in Iran, which provides an example of a cheap hostile signal: "And to the Iranian people, I say tonight: As you stand for your own liberty, America stands with you" (February 2, 2005). Cheap supportive relations include statements of support or offers of foreign aid. The following joint statement by the U.S. and Pakistani leaders provides an example: "President Bush and President Musharraf have affirmed the long-term, strategic partnership between their two countries ... based on the shared interests of the United States and Pakistan in building stable and sustainable democracy and in promoting peace and security, stability, prosperity, and democracy in South Asia and across the globe" (March 4, 2006). ${ }^{6}$ In Fearon's (1997) terms, these activities have low levels of "tying hands" and "sunk costs" because they do not require the signaler to make any significant investment to reinforce its position. While the United States might suffer some level of ex post audience costs from switching policy positions in the future, it would be far less than those for costly signals, such as wasting time and money to develop a trading infrastructure, negotiate an alliance, or mobilize troops. Because cheap signals are unlikely to credibly signal which side should expect external support if a civil war were to begin, they are unlikely to help the competing sides come to a mutually acceptable agreement to avoid the costs of fighting. Worse yet, cheap signals might actually introduce uncertainty into intrastate bargaining. The following section develops the logic of this argument.

5. Cheap signals are similar to the more common term used in the literature: cheap talk. Farrell and Rabin (1996, 116) define cheap talk as "costless, nonbinding, nonverifiable messages that may affect the listener's beliefs." The key difference here is that cheap signals are assumed to have some level of costs and are able to affect payoffs.

6. See www.whitehouse.gov for a full text of each quote. 


\section{CHEAP SIGNALS, SHOCKS, AND THE DECISION TO REBEL}

The most common line of civil war research today draws on a rationalist framework to understand the decision to rebel. The most important factors affecting this decision include the status quo environment, probability of victory, expected benefits of a future victory, and costs of fighting (Mason and Fett 1996; Grossman 1999). Among these factors, many scholars have argued that the probability of victory is of primary importance (e.g., Johnson 1964; Van Belle 1996; Klandermans and Oegema 1987; Lichbach 1995). As Ginkel and Smith $(1999,293,301)$ explain, "One of the key factors affecting the mob's decision to rebel is the probability of success. . . . The mob must be convinced that a revolution is likely to succeed." Many authors have extended this argument, explaining that actions from external actors can dramatically affect people's predicted probability of victory if they were to stage a rebellion (Goldstone 2001). When support for states in the Soviet's sphere of influence declined in the late 1980s, for example, governments such as Czechoslovakia were on their own when confronting opponents (Ginkel and Smith 1999, 305). This lack of support emboldened the opposition, causing them to increase demands of the government. Returning to the bargaining framework, however, we recall that some divergence in expectations between the opposition and the government is needed for a change in the probability of victory to lead to the civil war. While a hostile signal from the external actor may change the opposition's probability of victory, this will not necessarily lead to a violent rebellion if both the government and opposition interpret the signals in the same manner. Some shock is necessary for a divergence in expectations between the opposition and government. The following paragraphs identify three causal mechanisms to explain why cheap signals from the international community-especially those showing hostilities toward the government — can introduce uncertainty into intrastate bargaining.

First, it is likely that the government is better informed than the opposition about the probability and extent of support (or hostility) from external actors if a civil war were to begin. This is because interstate relations happen almost exclusively between the governments of states due to internationally recognized norms of sovereignty (Ruggie 1993; Bartkus 1999, 191-2; Regan 2002, 61; Lake 2003). Because international actors recognize a government's right to control the situation within its borders, efforts by external actors to deal with the opposition are generally infrequent, covert, and frowned upon by the international community. Two scenarios are likely in this context. First, the government will correctly estimate external support for the opposition, while the opposition underestimates the likelihood of receiving external support if they were to begin a rebellion. This would not change the likelihood that a civil war begins because the opposition fails to take advantage of its external support, making no additional demands of the government. There will be no reason for the government to make concessions without demands, resulting in no change in the bargaining positions $\left(\mathrm{G}_{\mathrm{acc}}\right.$ and $\left.\mathrm{O}_{\text {acc }}\right)$. In the second scenario, civil war may become more likely if the government correctly identifies hostile external signals as disingenuous, while the opposition views them as credible. The government will have no need to alter its bargaining position $\left(G_{\text {acc }}\right)$ in this case because it is confident that the opposition will not have external support for their 
cause, making it easy to crush a rebellion if one is attempted. In contrast, if the opposition views the same signals as credible, they will increase demands of the government $\left(\mathrm{O}_{\text {acc }}\right.$ moves left $)$. This would decrease or eliminate the zone of mutually acceptable bargaining positions, making civil war onset more likely.

Even if we assume that the opposition and the government have identical levels of information, the manner in which they translate new information into bargaining positions provides a second mechanism by which cheap hostile signals may result in civil war. As McGinnis and Williams $(2001,61)$ explain, updating policy positions based on new information is costly. A pronounced asymmetry in the time necessary for two competing states to adjust their positions based on new information may lead to a divergence in their respective positions. McGinnis and Williams expect no major differences between the United States's and Russia's abilities to translate new information into policy positions. The same expectation is likely not true for the intrastate environment. Opposition groups rarely have a complex bureaucracy or decisionmaking structure, which allows the leader(s) to rapidly change policy positions based on new information (Collier et al. 2003). Governments rarely act as efficiently. Even a highly authoritarian government has some group allowing it to retain power, which forces it to refer potential policy changes to another body before changing the government's official position (Bueno de Mesquita et al. 2003). When cheap hostile signals are sent from the external actors, the opposition may rapidly demand concessions from the government because they are quicker to update their bargaining position based on the new information. If the government is too slow to respond due to bureaucratic inefficiencies, the opposition may interpret this as a rejection of their demands and rebel.

Examining the motives of opposition leaders offers a third way to explain how cheap hostile signals may lead to the onset of civil war. Two arguments suggest that the leaders of the opposition have higher payoffs for staging a rebellion compared to low-level combatants. First, leaders of a successful rebellion are likely to end up much better off than the low-level fighters, obtaining positions of leadership in the new government (Van Belle 1996, 111-2). For example, the successful overthrow of the Batista government in Cuba (1959) left Fidel Castro as the dictator of the country, while other leaders, such as "Che" Guevara, obtained high-level posts. This may also be true in cases of negotiated settlement. Following the settlement of the recent Sudanese civil war (1983-2005), Sudan People's Liberation Army (SPLA) rebel leader John Garang obtained the post of vice president as part of the deal (Crilly 2005). In contrast to the dramatic improvements for the lives of opposition leaders, the lives of the low-level combatants change very little or worsen, even after a successful rebellion (Collier et al. 2003). Second, rebel leaders often do not face the same consequences for losing a rebellion as do the low-level combatants. This is because they have the resources and connections to safely flee the area if defeat becomes inevitable, while the low-level combatants are at the mercy of the victors. After the failed insurgency in Zaire (1964), for example, the two key rebel leaders, Gbenye and Soumialot, went into exile in Cairo. In contrast, the low-level combatants were left at the mercy of the victorious government forces (Kinder and Hilgemann 1978, 268). Compared to low-level combatants, therefore, opposition 
leaders are likely to receive greater benefits for staging a successful rebellion and suffer fewer costs for a failed rebellion. ${ }^{7}$

If it is true that opposition leaders have a greater incentive to begin a rebellion than low-level opposition members, then the actions taken by these leaders provide a potential explanation for the divergence in acceptable policy positions. According to Kuran $(1989,42)$, the leadership of the opposition is expected to "detect and to help expose the incumbent regime's vulnerability" in order to promote their cause to the people in an effort to garner their support. To do this, leaders attempt to alter the perceived value of the status quo while struggling to redefine the success thresholds (Van Belle 1996, 128). External threats offer an opportunity for opposition leaders to rally support for their cause because they can point to a potential ally if a violent rebellion were to begin-intentionally overestimating the probability and extent of future support. This will increase the people's predicted probability of staging a successful rebellion, making them more likely to make demands of the government. In this case, the shock from the external actors is manufactured by the opposition elite, who expect to derive greater benefits from victory and fewer costs of defeat than the low-level combatants.

The argument made in the paragraphs above posits three causal mechanisms to connect cheap hostile signals to the onset of civil war. Returning to the rational expectations framework, we can expect each of these mechanisms to lead to a divergence between positions that are mutually acceptable to both the government and opposition. In the bargaining framework presented in Figure 1, we should expect cheap hostile signals to cause the opposition to extend their demands beyond what is acceptable to the government $\left(\mathrm{O}_{\text {acc }}\right.$ moves left of $\left.\mathrm{G}_{\mathrm{acc}}\right)$. If the government is unwilling (or unable) to adjust to these demands, it is likely that the opposition will stage a rebellion.

The final type of signal to discuss is those that are cheap and supportive of the government. While these signals may introduce uncertainty into intrastate negotiations, they should work in the opposite manner as cheap hostile signals. From the government's point of view, supportive signals indicate to the leaders that they have a potential ally in the case of rebellion. When Bush declared support for the Pakistani government, for instance, he signaled an interest in maintaining the internal stability of its partner. If a rebellion is begun in this context, the threatened government can either expect help from the external partner or can at least assume that the partner will not aid the opposition. The support might also allow the state to devote more resources toward controlling the population within its borders. Informal signals of support from the United States to the Pinochet regime in Chile (19731989), for example, aided the government's efforts to brutally repress any semblance of opposition in the country. This impeded oppositional efforts to overthrow the government (Dinges 2004; Kornbluh 2004).

7. While these two claims are similar to those recently made in the interstate context (Chiozza and Goemans 2004), the second is perhaps counterintuitive given that we might expect rebel leaders to be killed for their crimes (rather than fleeing safely), while low-level combatants are allowed to reintegrate into society. Ultimately, this is an empirical question that has yet to be addressed by the literature. Furthermore, the empirical reality regarding the consequences of defeat is not as important as the prewar belief of these consequences, which may be impossible to capture in an empirical model. 
From the opposition's point of view, cheap supportive relations signal that their government will likely have external aid if a rebellion is attempted. At the very least, the opposition will not expect support on their behalf if they were to begin a rebellion. In either case, cheap supportive signals will work to lower the opposition's predicted probability of staging a successful rebellion due to the increased capability of the government. This will confound efforts from the opposition leader(s) to rally support from the people, making civil war an unlikely prospect. In the bargaining context, cheap supportive signals will cause the opposition to shift their acceptable position $\left(\mathrm{O}_{\text {acc }}\right)$ toward the government's side (to the right in Figure 1), resulting in a larger zone of mutually acceptable bargaining positions.

Overall, cheap signals should have an important effect on a state's internal stability. Cheap hostile signals should increase the likelihood that a civil war begins, while cheap supportive signals should have a pacifying effect. This leads to the second hypothesis:

Hypothesis 2: As cheap signals sent from external actors become more supportive, the probability of civil war onset should decrease.

Thus far, predictions have been made for four types of signals: costly/supportive, costly/hostile, cheap/supportive, and cheap/hostile. An assumption about cheap signals is that they are unpredictable and, therefore, may act as shocks to intrastate bargaining. However, it is possible that cheap signals that are consistent over time act more like costly signals because they are easy to predict. For example, over the past several decades, the United States has consistently sent cheap hostile signals to Cuba and cheap supportive signals to Canada. ${ }^{8}$ It is unlikely that these signals act as shocks to the intrastate bargaining framework because they can be readily predicted based on past signals. In contrast, relations between the United States and several Latin American states have been far more volatile. For example, the United States provided invariant support of the ruling regime in Nicaragua from the time Anastasio Somoza García assumed power in 1933 (Booth 1985). The support for the Somoza dynasty changed rapidly in 1977 when President Carter-eager to unveil his new human rights policy — chose to punish the Somoza regime for human rights violations by threatening to withdraw aid (LeoGrande 1979). This change in policy had a dramatic impact. As Grynspan (1991, 98) notes, "After 1977, the US government refused to support Somoza and slowly joined Somoza's opposition and regional leaders in demanding his resignation. The withdrawal of US support both weakened Somoza's regime and encouraged his opponents." Ultimately, this shock helped spur a rebellion by the Sandinista National Liberation Front (FSLN) opposition group in January 1978, resulting in a regime change the following year (Williamson 1999, 60).

Two types of shocks are possible in this context: negative and positive. Carter's change in policies toward Nicaragua is an example of a negative shock, where relations quickly changed from being supportive to hostile. Remaining consistent with the logic

8. The World Events Interaction Survey (WEIS) data set records 156 of 187 (83 percent) hostile relations between Cuba and the United States and 74 of 97 (76 percent) supportive relations between Canada and the United States from 1980 to 1993. 
of the weak signaling argument, we should expect negative shocks to increase the likelihood of civil war due to informational asymmetries, bureaucratic inefficiencies, or incentives for opposition leaders to manufacture a rebellion. The expectation here differs from the weak signaling argument by dropping the assumption that weak signals are inherently shocking, preferring instead to examine how signals change over time. This expectation leads to the third hypothesis:

Hypothesis 3: When signals sent from external actors switch from supportive to hostile (negative shock), the probability of civil war onset should increase.

A positive shock is when an external actor switches from being hostile to supportive. Consistent with the weak signaling argument, positive shocks provide the government with unexpected support, depressing the opposition's probability of staging a successful rebellion. This will ultimately force the opposition to lower its demands, making civil war onset less likely. Support from a variety of international actors following the devastating civil war in Sierra Leone (1991-2000) provides such an example. After years of condemning the government for atrocities committed during the war, actors such as the United States and the United Nations (UN) invested billions of dollars to support the government in an effort to ensure postwar peace. Walter (2002) provides a similar theoretical argument, explaining that support from external actors is integral to forcing ex-combatants to commit to post-civil war settlements. Thus, even in postwar societies, where the risk of civil war is extremely high, positive shocks can prevent the opposition from making excessive demands of the government. This expectation leads to the final hypothesis:

Hypothesis 4: When signals sent from external actors switch from hostile to supportive (positive shock), the probability of civil war onset should decrease.

\section{DATA, MEASUREMENT, AND MODELS}

This study builds on several recent empirical models for a quantitative test of the hypotheses. The unit of analysis is the country-year for all countries from 1945 to 1999. The dependent variable, civil war onset, is coded 1 for each country-year in which a civil war began and 0 otherwise. Civil war data come from the Uppsala/Peace Research Institute of Oslo (PRIO) data set, which defines armed conflict at a "contested incompatibility that concerns government and/or territory where the use of armed force between two parties, of which at least one is the government of a state, results in at least 25 battle-related deaths" (Gleditsch et al. 2002, 18). These data record 172 cases of civil war onset from 1945 to 1999 (2.65 percent of country-years). ${ }^{9}$ To control for temporal dependence, I include a variable counting

9. Results were also run using an alternative definition of "civil war onset" from Fearon and Laitin (2003). Results using this alternative, as well as the many alternative independent variables and control variables mentioned in subsequent footnotes, yield substantively identical results to those presented in this article unless otherwise noted. All results mentioned in the footnotes are available from the author upon request. 
the number of years without a civil war with natural cubic splines (Beck, Katz, and Tucker 1998). All independent variables are lagged one year.

The first hypothesis predicts that costly signals will have little effect on the probability of civil war onset. Four indicators are used to operationalize costly signals. Economic sanctions and militarized interstate disputes (MIDs) are used to capture costly hostile relations, while trade ties and alliances are used as indicators for costly supportive relations. ${ }^{10}$ Each of these is considered costly because it is readily observable ex ante and is apt to change slowly over time. Recent events in the Middle East provide examples of these characteristics for the costly hostile measures. Over the past several months, international actors have openly debated whether to apply sanctions on Iran for its development of nuclear technology. According to my argument, rebellion in Iran is most likely to happen in its current phase, where signals are cheap and few actors have made costly investments in reforming Iranian policies. By the time the signals become costly (e.g., the United States applies sanctions or mobilizes troops against Iran), either a rebellion would have already begun, or the Iranian government would be forced to make concessions to the opposition to avoid rebellion.

The costly supportive measures (alliances and trade ties) are also transparent and readily observable. Building on work from Morrow (1994), Smith $(1995,1998)$, and Fearon (1997), Leeds (2003) explains that formal alliances clearly signal to potential attackers that the allied states have a stake in each other's security. Although her discussion focuses on interstate disputes, we should expect the signal to reach potential attackers within the state as well. The discussion of trade in the democratic peace literature yields a similar expectation. By creating strong commercial ties, states invest themselves in the security of the other state and thus have a vested interest in maintaining the security of their trading partners (Russett and Oneal 2001; Oneal, Russett, and Berbaum 2003). Trade ties between the United States and China, for instance, have been growing for decades. While the United States likely agrees with the opposition's efforts to promote democracy in China, its costly trade ties with the current government clearly signal that it would not support a rebellion if one were to begin. Each of the costly indicators should be insignificant predictors of civil war onset to support the first hypothesis.

The second hypothesis predicts that the probability of civil war will decrease as cheap signals become more supportive of the government. Two events data sets are used to operationalize cheap signals. The first is the Conflict and Peace Data Bank (COPDAB), which codes daily interactions between states on an intensity scale ranging from -92 (most conflictual) to +102 (most supportive) from 1948 to 1978

10. Sanctions is a dummy variable coded 1 for any year in which a state had a sanction placed on it by any other state (Drury 1998). The first militarized interstate dispute (MID) variable records the number of MIDs the state experienced from any country (Singer and Small 1994). The second MID variable limits the indicator for neighbors only. Trade ties is a monadic indicator of total trade for each country-year (in 100,000s). For neighbors, I include the mean total trade for all contiguous dyads. Monadic and dyadic trade data come from Barbieri (2002) and Gleditsch (2002), respectively. Alliances is a count of the number of alliances (defense pact, neutrality, or entente) each state has with any other country in a given year (Gibler and Sarkees 2004). For neighbors, I include the percentage of neighbors with which each state has a formal alliance in each country-year. Several alternative indicators are used for the costly variables, including Signorino and Ritter's (1999) S scores for costly supportive relations. 
(Azar 1980). The second data set is the World Events Interaction Survey (WEIS), which codes similar events into sixty-three nominal categories (McClelland 1978). These nominal categories are recoded following Goldstein (1992), who places the WEIS codes on a conflict/cooperation continuum ranging from -10 (most conflictual) to +8.3 (most supportive). Because the scale for COPDAB uses larger values than WEIS, I follow Reuveny and Kang $(1996,299)$ by splicing the two data sets in the overlapping periods (1966-1978) with the following formula:

$$
\mathrm{WEIS}_{t}=C_{0}+C_{1} \cdot \mathrm{COPDAB}_{t}+e_{t}
$$

After splicing the dyadic measure, I then aggregate the data annually, resulting in a mean yearly level of conflict/cooperation between all dyads in the world. ${ }^{11}$ At this point, the unit of analysis is the directed-dyad year. Because civil war happens within a single state and covariates (explained below) are at the state level, I follow previous scholars such as Davis and Ward (1990), Leeds and Davis (1997), and Moore and Lanoue (2003) in collapsing all interstate interactions from dyads by target-year. Furthermore, given that the vast majority of dyads have few (if any) interactions in a given year, I limit the data to interactions between politically relevant dyads (PRDs), which consist of all contiguous states and major powers. This aggregation allows me to delete obscure dyads (e.g., Guatemala/Pakistan) from the data set, while including relevant dyads (e.g., United States/Singapore), which have many interactions due to the expansive foreign policy of the major powers. After collapsing the data by mean/target/year and lagging it one year, the result is a single yearly value ranging from -10 (most conflictual) to +8.3 (most supportive) for the mean event received by each state from PRDs from 1949 through 1993. As a final step, this measure is broken down into two categories. The first includes the entire continuum. The second limits the events to values that capture the theoretical definition of cheap signals-excluding events that have high ex ante or ex post costs. This drops events such as "military attack" and "armed force mobilization" on the hostile side, as well as events such as "make substantive agreement" and "extend military assistance" on the supportive side. ${ }^{12}$ This breakdown avoids potential bias that would arise if extreme events at the end of the conflict/cooperation continuum were driving the results, rather than cheap signals. We should expect to see a negative and significant coefficient for this variable to support the second hypothesis.

The third hypothesis predicts that the probability of civil war onset should increase when cheap signals change from being supportive to hostile (negative shock). The fourth hypothesis predicts the opposite effect when cheap signals switch from being hostile to supportive (positive shock). Three measures are used to capture these concepts. To create the first measure, volatility, I subtract the signal in time $t$ from the signal in $t-1$ to capture increases in levels of support or hostilities. Positive values indicate increased support for the government (positive shock), while negative values indicate increased hostilities (negative shock). A negative and significant coefficient

11. This approach is similar to past work from Polachek (1997), Leeds (1999), and Lebovic (2004), who also use a yearly aggregation of Conflict and Peace Data Bank (COPDAB) and/or WEIS events data. See Shellman (2004) for an excellent discussion of temporal aggregation of events data.

12. See Goldstein $(1992,376-7)$ for a complete list of events. 
for this variable would indicate support for both hypotheses 3 and 4 . One problem with this measure is that a move from a highly supportive signal (e.g., "promise material support") to a moderately supportive signal (e.g., "endorse other's policy or position") would be counted as a negative shock. This may be unrealistic given that both events are supportive of the government. Also, a single measure makes it difficult to parse out potential differences between positive and negative shocks. Therefore, I create two dummy variables that indicate when the signal crosses over "neutral" from year to year. The first, positive shock, is coded 1 if the signal in time $t-1$ is negative and the signal in time $t$ is positive ( 0 otherwise). The second, negative shock, is coded 1 if the signal in time $t-1$ is positive and the signal in time $t$ is negative ( 0 otherwise). We should expect the variable for negative shock to be positive and significant to support the third hypothesis, while the variable for positive shock should be negative and significant to support the fourth hypothesis.

Several variables found to be important in past models are included as control variables. Due to space constraints, I simply introduce the variables here. The reader is encouraged to review the original papers for a more thorough explanation of these variables. The first two variables, wealth and population, are indicators of state capacity and/or opportunity costs. Similarly, mountainous terrain is included as a proxy for state strength. The fourth variable, oil exporter, tests the argument that oil producers tend to have weak state apparatuses. Instability captures possible weakness and disorganization in states that have recently become independent or have undergone major transitions. The final two variables, anocracy and democracy, test whether regime type helps explain the probability of civil war onset. ${ }^{13}$

\section{DATA ANALYSIS}

The first hypothesis predicts that costly signals should have little effect on the probability that a civil war begins. This hypothesis is tested in Table 1. Each costly variable is run separately to avoid problems with collinearity and then combined in model 8 . These results provide strong support for the first hypothesis. The $p$-values for all costly variables (except total trade) range from .36 to .91 , which are far above any standard level for significance. Total trade is significant in model 4 , though this variable is likely acting as a proxy for wealth given that the gross domestic product (GDP)/capita measure drops from significance in the same model. Trade was also found to be an insignificant predictor of civil war onset from Barbieri and Reuveny (2005, 1241), providing further evidence that this variable does little to predict the onset of civil war. The control variables in Tables 1 and 2 remain largely consistent with past findings (e.g., Fearon and Laitin 2003; Hegre and Sambanis 2005).

The second hypothesis predicts that the probability of civil war onset will decrease as cheap signals become more supportive. This expectation is tested in Table 2 (models 1-3 and 6) with the variable for cheap signals. The first model presents the entire variable, ranging from -10 to +8.3 , which produces an insignificant

13. Data for wealth (gross domestic product [GDP]/capita) and population come from Gleditsch (2002). Data for all other variables come from Fearon and Laitin (2003). 


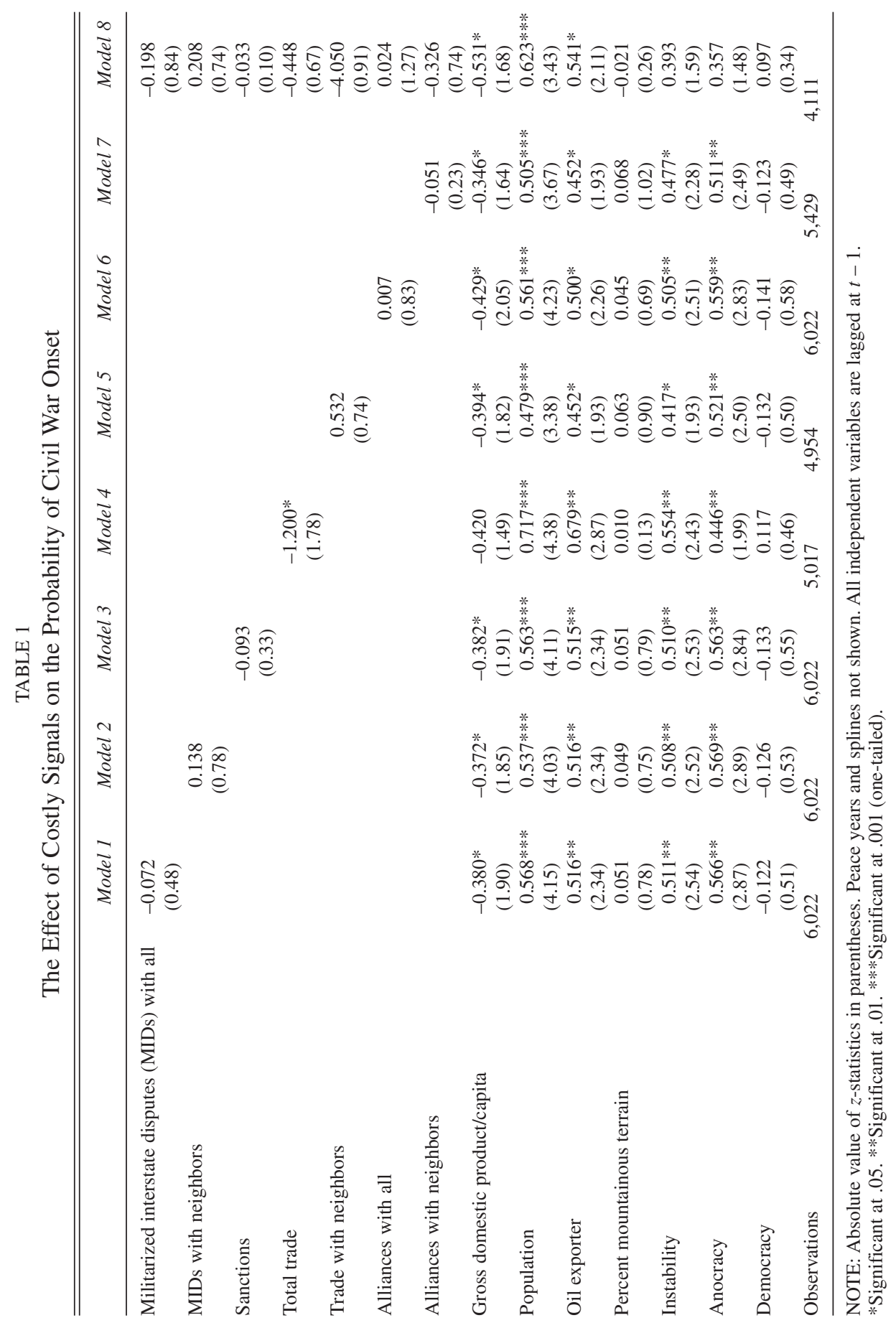




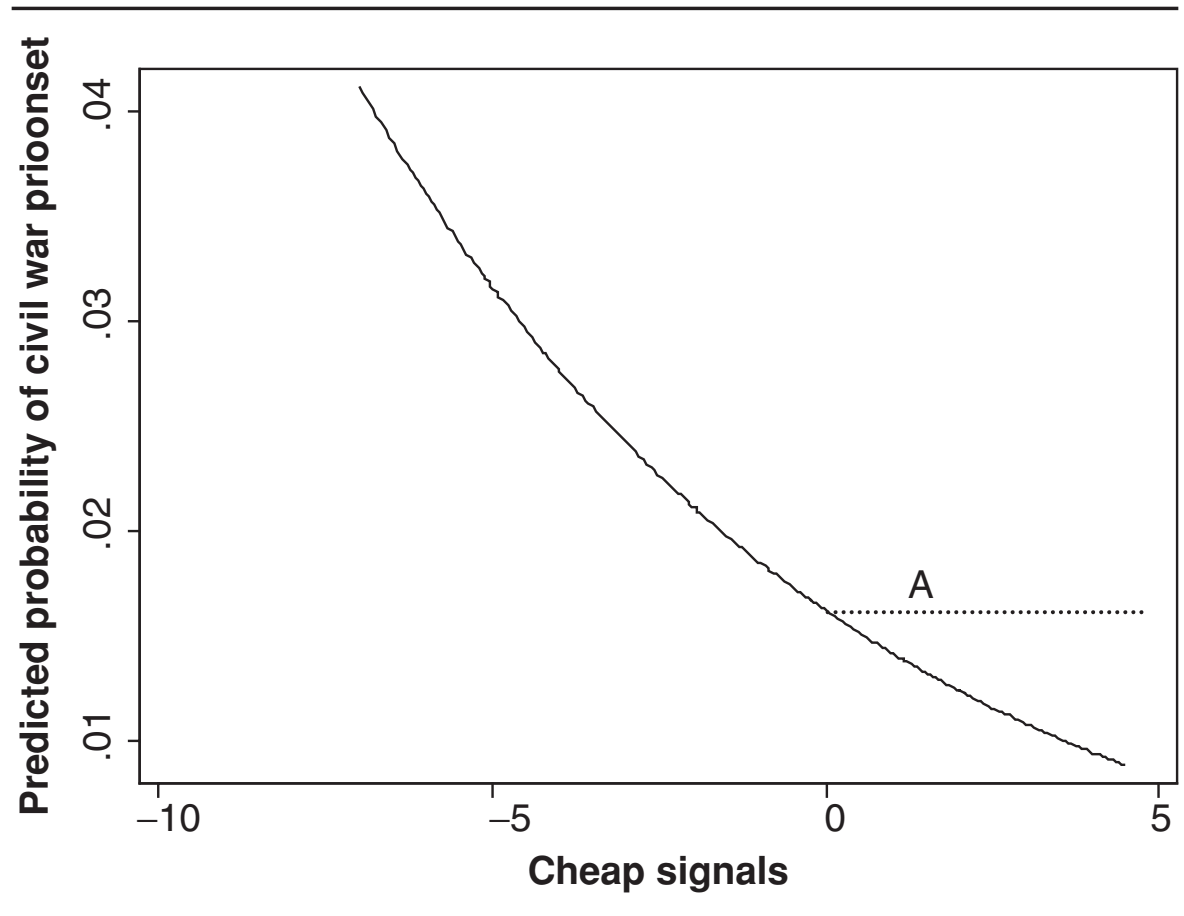

Figure 2: Marginal Effect of Cheap Signals on the Probability of Civil War Onset

coefficient. This result is unsurprising because the entire range of cheap signals includes many signals that are considered to be costly. We find the expected result in models 2 and 3 when the costly events are removed from the conflict/cooperation continuum. The results remain strong when the costly signaling variables are included as controls in model 6, which allows us to see how the new information provided by cheap signals affects the likelihood of civil war when holding the costly signals constant. Overall, these results provide strong support for the second hypothesis. Not only is the variable for cheap signals significant, but substantively, it also provides a fair amount of leverage in explaining civil war. A move from the minimum value $(-7)$ to the maximum value $(+4.5)$ in model 3 accounts for a 79 percent decrease in the probability of civil war onset (.049 to .010).

Figure 2 shows the marginal effect of the cheap signals variable, providing a couple of interesting observations beyond those given by the coefficients alone. First, these results provide evidence that friendly interstate interactions have a pacifying effect on civil conflict, which has not been examined in previous research. If friendly interstate interactions had no effect, we would expect the marginal effect to flatten out along the path indicated by line $A$. As we can see, the effect of friendly interstate signals continues to decrease the probability of civil war beyond what current evidence shows. Second, the marginal effect seems to flatten out in a convex shape as relations become 
friendlier. This suggests that while both friendly and hostile interactions matter, hostile relations are likely to have a greater effect in inciting rebellion that friendly relations will have in preventing rebellion. This provides an interesting topic for future studies.

The third hypothesis predicts that negative shocks will increase the probability of civil war onset, which is also tested in Table 2. The first indicator for this variable, volatility, captures changes in signals from the previous year (models 4 and 6). This measure is insignificant, indicating that yearly changes alone do not affect the likelihood that a civil war begins. As noted earlier, this finding is not altogether unexpected because a change in signals from highly supportive to moderately supportive is counted as a negative change, although both are signals of support for the government (the opposite is true for changes in hostilities). A more valid measure of this concept, negative shock, is included in models 5 and 6 . As expected, this variable is positive and significant in both models, indicating strong support for the third hypothesis. ${ }^{14}$ The substantive effect for this variable is substantial, with a 117 percent increase in the probability of civil war (.013 to .027) when a negative shock is present.

In a more concrete example of these findings, Figure 3 shows the events received by Nicaragua from the United States in the decade leading to the onset of civil war (1978). The dashed line represents the probability of civil war based on the predictions without interstate variables included in the model. The solid line represents the prediction after adding the variable for negative shocks. In the period from 1970 through 1976, Nicaragua consistently received friendly signals from the United States, which is represented with a lower predicted value of civil war onset compared to the baseline model. In 1977, Nicaragua received a series of cheap hostile signals, dramatically increasing its probability of civil war by 87 percent in a single year (.012 to .022). Consistent with the theory, these events clearly contributed to the onset of civil war in January 1978.

The final hypothesis predicts that positive shocks will decrease the probability of civil war onset. This expectation is tested in Table 2 (models 5 and 6). Surprisingly, this measure is positive and significant. This finding runs contrary to my theory, which expects the likelihood of civil war to decrease when the government receives unexpected support. A return to the bargaining model helps clear up these findings. In the theoretical section, I presented three causal mechanisms to explain why the opposition might make excessive demands of the government when cheap hostile signals are sent. The same logic can be used to explain why cheap supportive signals might also increase the likelihood that a civil war begins. Instead of simply allowing the government to maintain the status quo, the results indicate that cheap supportive signals cause the government to make demands of the opposition $\left(\mathrm{G}_{\mathrm{acc}}\right.$ moves right in Figure 1). If these demands are excessive, it is likely that the opposition will rebel despite the external support for the government.

The most recent civil war in Sudan (1983-2005) provides an example of this process. After granting extensive concessions to the non-Islamic opposition following the first Sudanese civil war (1956-1972), the government reneged on many of its promises and imposed Islamic law on the whole country a decade later (GlobalSecurity .org 2005). One factor pushing this change was a dramatic increase in support coming

14. The shock variables are positive but insignificant using Fearon and Laitin's (2003) dependent variable. 
TABLE 2

The Effect of Cheap Signals on the Probability of Civil War Onset

\begin{tabular}{|c|c|c|c|c|c|c|}
\hline & Model 1 & Model 2 & Model 3 & Model 4 & Model 5 & Model 6 \\
\hline Cheap signals & $\begin{array}{r}-0.092 \\
(1.58)\end{array}$ & $\begin{array}{l}-0.137 * \\
(2.04)\end{array}$ & $\begin{array}{l}-0.137 * \\
(1.89)\end{array}$ & & & $\begin{array}{l}-0.156^{*} \\
(1.65)\end{array}$ \\
\hline Volatility & & & & $\begin{array}{c}-0.028 \\
(0.00)\end{array}$ & & $\begin{array}{l}79.454 \\
(1.01)\end{array}$ \\
\hline Negative shock & & & & & $\begin{array}{l}0.763 * * \\
(2.52)\end{array}$ & $\begin{array}{l}0.675^{*} \\
(1.71)\end{array}$ \\
\hline Positive shock & & & & & $\begin{array}{l}0.776^{* *} \\
(2.56)\end{array}$ & $\begin{array}{l}0.770^{* *} \\
(2.03)\end{array}$ \\
\hline $\begin{array}{l}\text { Militarized interstate disputes } \\
\text { (MIDs) with all }\end{array}$ & & & $\begin{array}{r}-0.261 \\
(1.08)\end{array}$ & & & $\begin{array}{r}-0.243 \\
(1.02)\end{array}$ \\
\hline MIDs with neighbors & & & $\begin{array}{r}0.243 \\
(0.86)\end{array}$ & & & $\begin{array}{r}0.199 \\
(0.71)\end{array}$ \\
\hline Sanctions & & & $\begin{array}{c}-0.080 \\
(0.25)\end{array}$ & & & $\begin{array}{c}-0.142 \\
(0.44)\end{array}$ \\
\hline Total trade & & & $\begin{array}{r}-0.395 \\
(0.60)\end{array}$ & & & $\begin{array}{r}-0.541 \\
(0.79)\end{array}$ \\
\hline Trade with neighbors & & & $\begin{array}{c}-3.984 \\
(0.93)\end{array}$ & & & $\begin{array}{c}-3.846 \\
(0.91)\end{array}$ \\
\hline Ally with all & & & $\begin{array}{r}0.029 \\
(1.46)\end{array}$ & & & $\begin{array}{r}0.027 \\
(1.39)\end{array}$ \\
\hline Ally with neighbors & & & $\begin{array}{c}-0.419 \\
(0.92)\end{array}$ & & & $\begin{array}{c}-0.384 \\
(0.84)\end{array}$ \\
\hline $\begin{array}{l}\text { Gross domestic } \\
\text { product/capita }\end{array}$ & $\begin{array}{l}-0.661 * * \\
(2.70)\end{array}$ & $\begin{array}{l}-0.690 * * \\
(2.77)\end{array}$ & $\begin{array}{l}-0.631^{*} \\
(1.96)\end{array}$ & $\begin{array}{l}-0.663^{* *} \\
(2.65)\end{array}$ & $\begin{array}{l}-0.737 * * \\
(2.96)\end{array}$ & $\begin{array}{l}-0.733^{*} \\
(2.27)\end{array}$ \\
\hline Population & $\begin{array}{l}0.523 * * * \\
(3.66)\end{array}$ & $\begin{array}{l}0.541^{* * *} \\
(3.72)\end{array}$ & $\begin{array}{l}* .661 * * \\
(3.58)\end{array}$ & $\begin{array}{l}0.569 * * * \\
(3.89)\end{array}$ & $\begin{array}{l}* 0.530 * * * \\
(3.63)\end{array}$ & $\begin{array}{l}* 0.686^{* * * *} \\
(3.68)\end{array}$ \\
\hline Oil exporter & $\begin{array}{l}0.704 * * \\
(3.02)\end{array}$ & $\begin{array}{l}0.744 * * * \\
(3.18)\end{array}$ & $\begin{array}{l}* .600^{* *} \\
(2.33)\end{array}$ & $\begin{array}{l}0.754 * * * \\
(3.22)\end{array}$ & $\begin{array}{l}* 0.738^{* * *} \\
(3.14)\end{array}$ & $\begin{array}{l}0.608^{* *} \\
(2.35)\end{array}$ \\
\hline Percent mountainous & $\begin{array}{r}0.021 \\
(0.30)\end{array}$ & $\begin{array}{c}0.004 \\
(0.05)\end{array}$ & $\begin{array}{r}-0.047 \\
(0.57)\end{array}$ & $\begin{array}{c}-0.010 \\
(0.13)\end{array}$ & $\begin{array}{r}-0.007 \\
(0.10)\end{array}$ & $\begin{array}{c}-0.060 \\
(0.72)\end{array}$ \\
\hline Instability & $\begin{array}{l}0.604 * * \\
(2.74)\end{array}$ & $\begin{array}{l}0.577 * * \\
(2.58)\end{array}$ & $\begin{array}{c}0.348 \\
(1.39)\end{array}$ & $\begin{array}{l}0.585^{* *} \\
(2.58)\end{array}$ & $\begin{array}{l}0.568 * * \\
(2.53)\end{array}$ & $\begin{array}{c}0.333 \\
(1.32)\end{array}$ \\
\hline Anocracy & $\begin{array}{l}0.558 * * \\
(2.57)\end{array}$ & $\begin{array}{l}0.618^{* *} \\
(2.82)\end{array}$ & $\begin{array}{l}0.423^{*} \\
(1.74)\end{array}$ & $\begin{array}{l}0.575^{* *} \\
(2.59)\end{array}$ & $\begin{array}{l}0.622 * * \\
(2.83)\end{array}$ & $\begin{array}{l}0.420^{*} \\
(1.72)\end{array}$ \\
\hline Democracy & $\begin{array}{c}0.086 \\
(0.33)\end{array}$ & $\begin{array}{r}0.112 \\
(0.43)\end{array}$ & $\begin{array}{c}0.138 \\
(0.47)\end{array}$ & $\begin{array}{r}0.075 \\
(0.29)\end{array}$ & $\begin{array}{r}0.124 \\
(0.47)\end{array}$ & $\begin{array}{r}0.199 \\
(0.67)\end{array}$ \\
\hline Observations & 5,101 & 5,021 & 4,041 & 5,005 & 5,021 & 4037 \\
\hline $\begin{array}{l}\text { Area under receiver operating } \\
\text { characteristic (ROC) curve }\end{array}$ & 0.71 & 0.71 & 0.70 & 0.70 & 0.71 & 0.71 \\
\hline $\begin{array}{l}\text { ROC vs. baseline } \\
\left(\text { Prob }>\chi^{2}\right)\end{array}$ & $\begin{array}{c}2.05 \\
(0.15)\end{array}$ & $\begin{array}{c}1.11 \\
(0.29)\end{array}$ & $\begin{array}{c}0.95 \\
(0.33)\end{array}$ & $\begin{array}{l}1.25 \\
(0.26)\end{array}$ & $\begin{array}{l}2.69 * \\
(0.10)\end{array}$ & $\begin{array}{r}2.69^{*} \\
(0.10)\end{array}$ \\
\hline
\end{tabular}

NOTE: Absolute value of $z$-statistics in parentheses. Peace years and splines not shown. All independent variables are lagged at $t-1$.

*Significant at .05. **Significant at .01. ***Significant at .001 (one-tailed). 


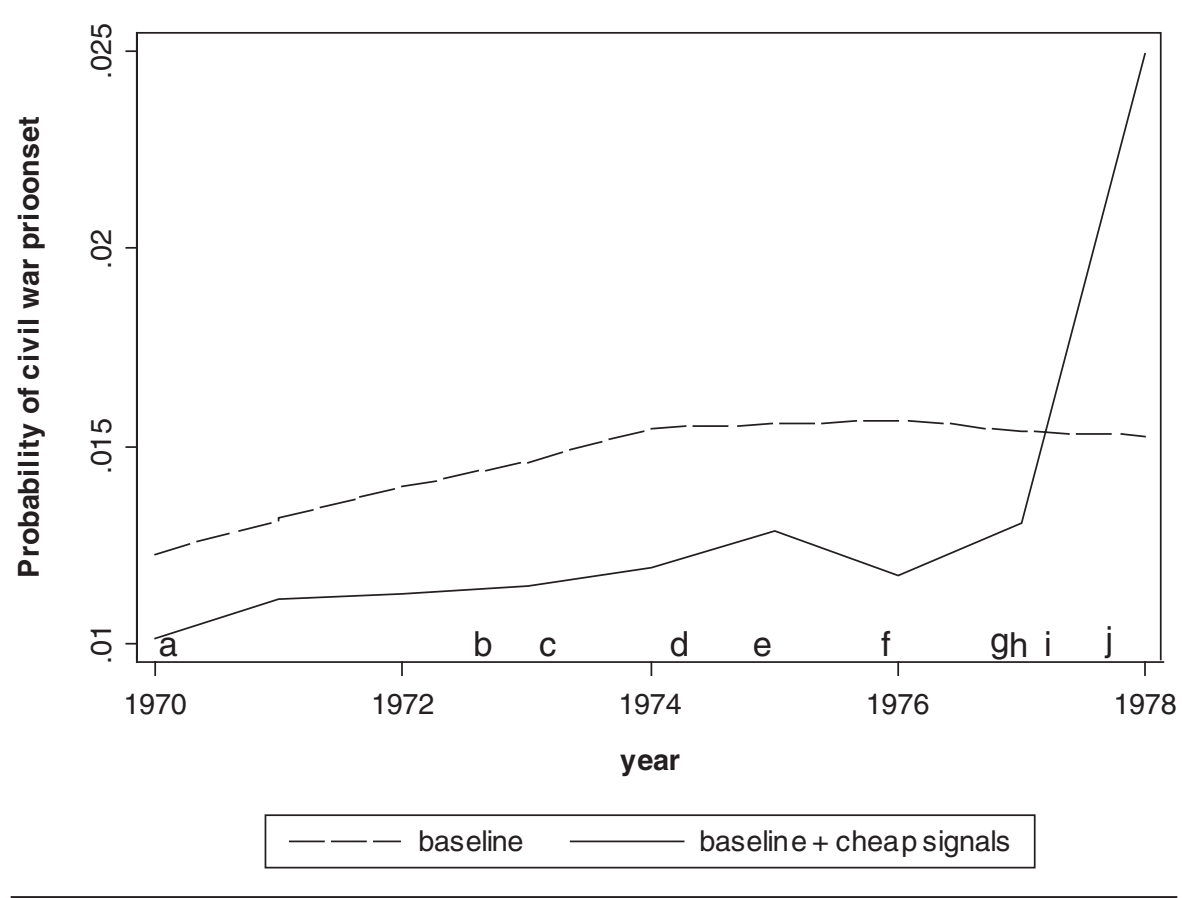

\section{Figure 3: Probability of Civil War Onset in Nicaragua, 1970-1978}

\begin{tabular}{llc}
\hline Code & Event & Value \\
\hline $\mathrm{a}$ & New Organization of American States (OAS) charter established (2/27/1970) & +14 \\
$\mathrm{~b}$ & Aid sent to Nicaraguan earthquake victims (12/25/1972) & +14 \\
$\mathrm{c}$ & OAS general assembly meets in Washington (04/16/1973) & +6 \\
$\mathrm{~d}$ & United States gives Nicaragua \$15 million for disaster relief (5/15/1974) & +27 \\
$\mathrm{e}$ & OAS meets in a special session to discuss the U.S. trade act $(1 / 20 / 1975)$ & +14 \\
$\mathrm{f}$ & Undersecretary of State Rogers meets with Somoza (2/06/1976) & +6 \\
$\mathrm{~g}$ & United States accuses Nicaraguan government of profiting from relief aid (3/23/1977) & -16 \\
$\mathrm{~h}$ & United States demands human rights improvements to receive relief aid $(4 / 06 / 1977)$ & -16 \\
$\mathrm{i}$ & United States withholds sale of arms due to human rights violations $(7 / 17 / 1977)$ & -29 \\
$\mathrm{j}$ & Civil war begins (1/10/1978) & - \\
\hline
\end{tabular}

Conflict and Peace Data Bank $($ COPDAB $)$ values: $+92=$ most supportive; $0=$ neutral event $;-102=$ most conflictual.

from Egypt in the months prior to the legal reforms. In an attempt to reinforce its security and reestablish itself as a leader among Arab states, Egypt reached out to Sudan in an effort to establish close ties between the two countries. As Egyptian President Mubarak noted, "Sudan's security [is] Egypt's security" (British Broadcasting Corporation [BBC] 1983). These events stand in stark contrast to earlier relations between the two countries, in which Egyptian President Sadat's signing of a peace agreement with Israel (1979) caused tension between the two states. Consistent with bargaining logic, the positive shock coming from Egypt contributed to the Sudanese 
government's decision to make objectionable demands of the opposition. Although the opposition had little chance of successfully overthrowing the government, the repressive policies left them to choose between the lesser of two evils: either endure escalating religious and cultural persecution or fight (Bartkus 1999, 137). They chose to fight. In the empirical model, the positive shock coming from Egypt caused the probability in civil war onset in Sudan to increase by 86 percent (.031 to .058) in the year prior to the onset of civil war.

The finding for the positive shock variable should also be reconciled with the findings for the cheap signals variable. The results for the cheap signals variable indicate that cheap supportive signals decrease the likelihood that a civil war begins, while the results for the positive shock variable indicate the opposite. This means that cheap signals of support that are consistent over time will decrease the likelihood that a civil war begins. In contrast, when the cheap supportive signals make a dramatic switch, the probability of civil war increases because the government is more likely to make objectionable demands of the opposition. Future research should probe these findings further, both theoretically and empirically, perhaps expanding the causal logic to explain why governments might make objectionable demands of the opposition. Using an alternative dependent variable, such as repression, might better capture changes in government behavior due to shocking signals.

Finally, the models themselves produce a strong fit overall. First, the chi-square values are all significant at the $<.001$ level. Second, the values for the area beneath the (receiver operating characteristic) curve range from .69 to .70, indicating that the models produce a fair model fit. ${ }^{15}$ More important than the fit for the entire model is the potential improvement of fit after adding the variables for interstate interactions. This is done with a chi-square test comparing the baseline model (excluding all variables for interstate relations) with the models including interstate signals. None of the models in Table 1 incorporating costly signal variables significantly improves the model fit. In contrast, the final two models in Table 2, which include the effects of cheap signals, negative shocks, and positive shocks, significantly improve upon the model's predictive power. This suggests that these variables should be strong candidates for future researchers attempting to predict the onset of civil war.

While the empirical results are robust, several possible criticisms should be addressed. First, the coding of the primary independent variable assumes that all interactions sent by states carry equal weight. To examine if strength of the sender affected the results in any way, I weighted events sent by the Composite Index of National Capability (CINC) score and Polity IV scores of the sender. ${ }^{16}$ In each instance, the results were consistent with those presented here. This finding is unsurprising given

15. The receiver operating characteristic (ROC) curve is a plot of the true-positive rate against the false-positive rate for the different possible cutpoints of a diagnostic test. See Tape (2005) for an excellent discussion.

16. The Composite Index of National Capability (CINC) score is an index including measures for total population, urban population, iron and steel production, energy consumption, military personnel, and military expenditure used as a common measure of state strength in international relations literature (Singer 1988). Polity IV is a measure of a state's regime type, in the form of their autocracy score subtracted from their democracy score to produce a variable that ranges from -10 (very autocratic) to 10 (very democratic) (Jaggers and Gurr 1995). 
that the states that send the costliest signals are likely to be those who have the power to back up the signals with action if necessary.

Second, the model may suffer from endogeneity. If a country experiences a civil war in the same year that it experiences hostile relations, for instance, the hostile relations may be a result of the civil war as states condemn the atrocities that are common to civil conflict. This is dealt with in the models by lagging the independent variables. However, it is possible that interstate relationships prior to $t-1$ influence the domestic stability of a state. Following Smith and Blundell (1986), I ran a twostage model to test for endogeneity. This test predicts the potential endogenous variables (signaling variables) in the first stage, then includes the residuals from the first stage into the second stage models (those presented in Table 2). ${ }^{17}$ Results from this test indicate that endogeneity is not a problem, with $p$-values ranging from .12 to .18.

Third, one might suggest that the rivalry between the United States and USSR during the cold war is driving the results. The current analysis averages signals from these two countries with other politically relevant states, potentially washing out any special effects that these signals might have. To examine this possibility, I ran the models after dropping the United States and USSR as possible signalers. The results remain largely consistent with those presented in Table 2, indicating that the effects of cheap signals are not simply a function of cold war rivalries. The only exception is that the indicator for positive shock becomes insignificant when signals from the United States and USSR are withheld from the analysis. This may indicate that governments were more likely to make excessive demands of the people during the cold war when they expected support from one of the two superpowers if a civil war were to arise. Overall, these results concur with past research in finding that the cold war has little effect on the probability of civil war onset (Sambanis 2001, 274-5; Fearon and Laitin 2003, 77).

\section{SUMMARY, CONCLUSIONS, AND IMPLICATIONS}

The purpose of this article was to examine the effect of interstate relations on the probability of civil war onset. Drawing on bargaining theory and rational expectations as frameworks for analysis, I predicted that intrastate relations between the government and opposition will remain peacefully stable in the vast majority of situations due to the high costs of conflict. Some shock is necessary for a divergence in acceptable bargaining positions. Interstate signals can provide this shock by affecting the opposition's and the government's bargaining positions. Costly signals will cause each actor to shift their position to adjust for changes in capabilities due to external support or hostilities. Because these signals are readily observable by both parties, there is no reason to expect a divergence in mutually acceptable bargaining positions.

17. The following model is used to predict interstate signals: interstate interactions $=$ total trade + income per capita + number of alliances with any country + oil exporter + new state + democracy dummy + anocracy dummy + number of state borders $+e$. Endogeneity was also examined by estimating a series of lags for both the dependent and independent variables analogous to tests of Granger causality with panel data. 
In contrast, cheap signals can introduce uncertainty into intrastate bargaining for three reasons. First, the government may interpret the signals differently than the opposition, increasing the likelihood that the opposition makes an unacceptable demand to the government. Second, the government may be slow to respond to the new signals due to bureaucratic inefficiencies. Third, leaders of the opposition may use the signals to encourage people to fight when the odds of success are low. Any of these three causal mechanisms can provide a shock to the otherwise peaceful intrastate bargaining process, increasing the likelihood that a civil war begins.

This theory was tested using data for militarized interstate disputes (MIDs), sanctions, alliances, and trade as indicators of costly signals. As expected, all of these variables were insignificant predictors of civil war onset. COPDAB and WEIS events data were used to operationalize cheap signals. These measures provided strong support for the cheap signaling argument. As cheap signals become more supportive, the probability of civil war onset decreases. Changes in cheap signals over time were also found to have an important effect. The probability of civil war onset increases when cheap signals switch from being supportive to hostile (negative shock). Surprisingly, the probability of civil war also increases when signals switch from being hostile to supportive (positive shock). This suggests that the government may make excessive demands of the opposition when it receives unexpected support. When cheap supportive signals are consistent with those in years past, however, the likelihood of civil war onset remains low.

Several important implications and avenues for future research can be drawn from this study. Researchers interested in examining the effect of international relations on the onset of civil war could disaggregate the cheap signaling variable in a number of ways to probe theoretically interesting questions. For example, do signals from democracies and nondemocracies have the same levels of credibility? What about signals sent from states with similar regime types or similar cultural characteristics? How might these trends change over time? More broadly, this study has shown how the bargaining framework common to the interstate war literature can help generate accurate predictions in the intrastate environment. Future research might examine how other factors might provide shocks to the intrastate environment. These factors may include natural disasters, the emergence of an influential leader, technological changes, the discovery (or loss) of natural resources, or shifts in the international power structure.

Scholars studying how external actors affect the duration and outcomes of civil wars can also find important implications in this study. Currently, these areas of research generally assume that interventions during a civil war are exogenous to the original decision to rebel (e.g., Regan 2002; DeRouen and Sobek 2004). However, this study provides strong evidence that both the government and opposition incorporate expectations for external aid or hostilities into their prewar decisions. Therefore, the effect of interventions on the duration and outcome of an ongoing civil war can only be understood in the context of that actor's prewar signal. One might argue that an intervention during the war that is consistent with this signal should have little effect on the duration and outcome of the conflict because it would 
have been expected by the competing parties. In contrast, interventions during the war that are inconsistent with the external actor's prewar signal likely have a dramatic effect because they are unexpected by the competing parties. Perhaps this is the reason that studies examining the effect of intervention on the duration of civil war have consistently found the counterintuitive result that intervention lengthens the duration of civil wars (e.g., Balch-Lindsay and Enterline 2000; Regan 2002).

The policy community can also find important implications in this study. Leaders should understand that both threats and statements of support can have a profound impact on violence in another country. Even seemingly cheap rhetoric, such as Carter's threat to withdraw aid from Nicaragua in 1977, likely plays a significant role in an opposition's decision to stage a rebellion. Similarly, statements of support have the potential to help a government maintain stability in the face of an otherwise imminent threat. If change is to come peacefully, states must make real investments to credibly signal their support for change. Cheap signals are apt to turn a poor peaceful environment into a violent conflict.

\section{REFERENCES}

Azar, Edward E. 1980. The Conflict and Peace Data Bank (COPDAB) project. Journal of Conflict Resolution 24:143-52.

Balch-Lindsay, Dylan, and Andrew Enterline. 2000. Killing time: The world politics of civil war duration, 1820-1992. International Studies Quarterly 44:615-42.

Barbieri, Katherine. 2002. The liberal illusion: Does trade promote peace? Ann Arbor: University of Michigan Press.

Barbieri, Katherine, and Rafael Reuveny. 2005. Economic globalization and civil war. Journal of Politics 67:1228-47.

Bartkus, Viva Ona. 1999. The dynamic of secession. Cambridge, MA: Cambridge University Press.

Beck, Nathaniel, Jonathan N. Katz, and Richard Tucker. 1998. Taking time seriously: Time-series crosssection analysis with a binary dependent variable. American Journal of Political Science 42:1260-88.

Blainey, Geoffrey. 1988. The causes of war. New York: Free Press.

Booth, John A. 1985. The end and the beginning: The Nicaraguan revolution. 2nd ed. Boulder, CO: Westview.

British Broadcasting Corporation (BBC). 1983. President Mubarak on Egypt's foreign and domestic policies. January 6, 1983.

Bueno de Mesquita, Bruce, James Morrow, Alastair Smith, and Randolph M. Siverson. 2003. The logic of political survival. Cambridge, MA: MIT Press.

Cetinyan, Rupen. 2002. Ethnic bargaining in the shadow of third-party intervention. International Organization 56:645-77.

Chiozza, Giacomo, and H. E. Goemans. 2004. International conflict and the tenure of leaders: Is war still ex post inefficient? American Journal of Political Science 48:604-19.

Collier, Paul, Lani Elliott, Havard Hegre, Anke Hoeffler, Marta Reynal-Querol, and Nicholas Sambanis. 2003. Breaking the conflict trap: Civil war and development policy. Washington, D.C.: The International Bank for Reconstruction and Development/The World Bank.

Crilly, Rob. 2005. Sudan may face renewed civil war. New Scotsman. Accessed May 8, 2005, from http://www.globalpolicy.org/security/issues/sudan/2005/0411developdraft.htm.

Danilovic, Vesna. 2001. Conceptual and selection bias issues in deterrence. Journal of Conflict Resolution 45:97-125. 
Davis, David, and Michael Ward. 1990. They dance alone: Deaths and the disappeared in Chile. Journal of Conflict Resolution 34:449-75.

DeRouen, Karl R., Jr., and David Sobek. 2004. The dynamics of civil war duration and outcome. Journal of Peace Research 41:303-20.

Dinges, John. 2004. The condor years: How Pinochet and his allies brought terrorism to three continents. New York: New Press.

Drury, A. Cooper. 1998. Revisiting economic sanctions reconsidered. Journal of Peace Research 35:497-509.

Farrell, Joseph, and Matthew Rabin. 1996. Cheap talk. Journal of Economic Perspectives 10:103-18.

Fearon, James D. 1994. Signaling versus the balance of power and interests: An empirical test of a crisis bargaining model. Journal of Conflict Resolution 38:236-69.

1995. Rationalist explanations for war. International Organization 49:379-414.

1997. Signaling foreign policy interests. Journal of Conflict Resolution 41:68-90.

Fearon, James D., and David Laitin. 2003. Ethnicity, insurgency, and civil war. American Political Science Review 97:75-90.

Fordham, Benjamin O. 2005. Strategic conflict avoidance and the diversionary use of force. Journal of Politics 67:132-53.

Gartzke, Erik. 1999. War is in the error term. International Organization 53:567-87.

Gibler, Douglas M., and Meredith R. Sarkees. 2004. Measuring alliances: The correlates of war formal interstate alliance dataset, 1816-2000. Journal of Peace Research 41:211-22.

Ginkel, John, and Alastair Smith. 1999. So you say you want a revolution: A game theoretic explanation of revolution in repressive regimes. Journal of Conflict Resolution 43:291-316.

Gleditsch, Kristian. 2002. Expanded trade and GDP data. Journal of Conflict Resolution 46:712-24.

- Forthcoming. Transnational dimensions of civil war. Journal of Peace Research.

Gleditsch, Kristian, and Kyle Beardsley. 2004. Nosy neighbors: Third-party actors in Central American conflicts. Journal of Conflict Resolution 48:379-402.

Gleditsch, Nils Petter, Peter Wallensteen, Mikael Eriksson, Margareta Sollenberg, and Håvard Strand. 2002. Armed conflict 1946-2001: A new dataset. Journal of Peace Research 39:615-37.

GlobalSecurity.org. 2005. Sudan civil war. Accessed August 4, 2005, from http://www.globalsecurity.org/ military/world/war/sudan.htm.

Goldstein, Joshua. 1992. A conflict-cooperation scale for WEIS international events data. Journal of Conflict Resolution 36:369-85.

Goldstone, Jack A. 2001. Toward a fourth generation of revolutionary theory. Annual Review of Political Science 4:139-87.

Grossman, Herschel. 1999. Kleptocracy and revolutions. Oxford Economic Papers 51:267-83.

Grynspan, Dévora. 1991. Nicaragua: A new model for popular revolution in Latin America. In Revolutions of the late twentieth century, edited by Jack A. Goldstone, Ted Robert Gurr, and Farrokh Moshiri. Boulder, CO: Westview.

Hegre, Håvard, and Nicholas Sambanis. 2006. Sensitivity analysis of the empirical literature on civil war onset. Journal of Conflict Resolution 50:508-35.

Jaggers, Keith, and Ted Robert Gurr. 1995. Polity III: Regime type and political authority, 1800-1994. Accessed December 26, 2005, from http://ssdc.ucsd.edu/ssdc/icp06695.html.

Johnson, Chalmers. 1964. Revolution and the social system. Stanford, CA: Hoover Institution on War, Revolution, and Peace.

Kilgour, Marc, and Frank C. Zagare. 1991. Credibility, uncertainty, and deterrence. American Journal of Political Science 35:305-34.

Kinder, Gary, and Werner Hilgemann. 1978. The Anchor atlas of world history, 2. Garden City, NY: Anchor.

Klandermans, Burt, and Dirk Oegema. 1987. Potentials, networks, motivations and barriers: Steps toward participation in social movements. American Sociological Review 52:519-31.

Kornbluh, Peter, ed. 2004. The Pinochet file: A declassified dossier on atrocity and accountability. New York: New Press.

Kuran, Timur. 1989. Sparks and prairie fires: A theory of unanticipated political revolution. Public Choice 61:41-74. 
Lake, David A. 2003. The new sovereignty in international relations. International Studies Review 5:303-23.

Lake, David A., and Donald Rothchild. 1998. Spreading fear: The genesis of transnational ethnic conflict. In The international spread of ethnic conflict: Fear, diffusion, and escalation, edited by David A. Lake and Donald Rothchild, 3-32. Princeton, NJ: Princeton University Press.

Lebovic, James H. 2004. Unity in action: Explaining alignment behavior in the Middle East. Journal of Peace Research 41:167-89.

Leeds, Brett Ashley. 1999. Domestic political institutions, credible commitments, and international cooperation. American Journal of Political Science 43:979-1002.

2003. Do alliances deter aggression? The influence of military alliances on the initiation of militarized interstate disputes. American Journal of Political Science 47:427-39.

Leeds, Brett Ashley, and David Davis. 1997. Domestic political vulnerability and international disputes. Journal of Conflict Resolution 41:814-34.

LeoGrande, William M. 1979. The revolution in Nicaragua: Another Cuba? Foreign Affairs 58:28-50.

Li, Quan, and David Sacko. 2002. The (ir)relevance of interstate militarized disputes to international trade. International Studies Quarterly 46:11-44.

Lichbach, Mark I. 1995. The rebel's dilemma. Ann Arbor: University of Michigan Press.

Manby, Brownwen. 1992. South Africa: The impact of sanctions. Journal of International Affairs 46:193-217.

Mason, David, and Patrick Fett. 1996. How civil wars end: A rational choice approach. Journal of Conflict Resolution 40:546-68.

McClelland, Charles. 1978. World event interaction survey [Computer file]. Los Angeles: University of Southern California.

McGinnis, Michael D., and John T. Williams. 2001. Compound dilemmas: Democracy, collective actions, and superpower rivalry. Ann Arbor: University of Michigan Press.

Moore, Will H. 1995. Action-reaction or rational expectations? Reciprocity and the domestic-international conflict nexus during the 'Rhodesia problem.' Journal of Conflict Resolution 39:129-67.

Moore, Will H., and David J. Lanoue. 2003. Domestic politics and US foreign policy: A study of cold war conflict behavior. Journal of Politics 65:376-96.

Morrow, James D. 1989. Capabilities, uncertainty, and resolve. American Journal of Political Science 33:941-72.

- 1994. Alliances, credibility, and peacetime costs. Journal of Conflict Resolution 38:270-97. 1999. How could trade affect conflict? Journal of Peace Research 36:481-9.

Oneal, John R., Bruce Russett, and Michael L. Berbaum. 2003. Causes of peace: Democracy, interdependence, and international organizations, 1886-1992. International Studies Quarterly 47:371-93.

Polachek, S. 1997. Why democracies cooperate more and fight less: The relationship between international trade and cooperation. Review of International Economics 5:295-309.

Powell, Robert. 1999. In the shadow of power: States and strategies in international politics. Princeton, NJ: Princeton University Press.

. 2002. Bargaining theory and international conflict. Annual Review of Political Science 5:1-30.

Regan, Patrick. 2002. Third-party interventions and the duration of intrastate conflicts. Journal of Conflict Resolution 46:55-73.

Regan, Patrick, and Aysegul Aydin. 2005. Diplomacy and other forms of intervention in civil wars. Journal of Conflict Resolution 50:736-56.

Reiter, Dan. 2003. Exploring the bargaining model of war. Perspectives on Politics 1:27-43.

Reuveny, Rafael, and Heejoon Kang. 1996. International conflict and cooperation: Splicing COPDAB and WEIS series. International Studies Quarterly 40:281-305.

Ruggie, John G. 1993. Territoriality and beyond: Problematizing modernity in international relations. International Organizations 47:139-74.

Russett, Bruce, and John Oneal. 2001. Triangulating peace: Democracy, interdependence, and international organizations. New York: Norton.

Salehyan, Idean, and Kristian Gleditsch. 2006. Refugees and the spread of civil war. International Organization 60 (2): 335-66. 
Sambanis, Nicholas. 2001. Do ethnic and non-ethnic civil wars have the same causes? A theoretical and empirical inquiry. Journal of Conflict Resolution 45:259-82.

Shellman, Stephen. 2004. Time series intervals and statistical inference: The effects of temporal aggregation on event data analysis. Political Analysis 12:97-104.

Signorino, Curtis S., and Jeffrey M. Ritter. 1999. Tau-b or not Tau-b: Measuring the similarity of foreign policy positions. International Studies Quarterly 43:115-44.

Singer, J. David. 1988. Reconstructing the correlates of war data set on material capabilities of states, 1816-1985. International Interactions 14:115-32.

Singer, David, and Melvin Small. 1994. Correlates of war project: International and civil war data, 18161992 [Computer file]. ADDRESS: CISER. Access year, 2004.

Smith, Alastair. 1995. Alliance formation and war. International Studies Quarterly 39:405-25. 1998. Extended deterrence and alliance formation. International Interactions 24:315-43.

Smith, Richard J., and Richard W. Blundell. 1986. An exogeneity test for a simultaneous equation Tobit model with and application to labor supply. Econometrica 54:679-85.

Tape, Thomas G. 2005. Interpreting diagnostic tests. University of Nebraska Medical Center. Accessed August 4, 2005, from http://gim.unmc.edu/dxtests/Default.html.

Van Belle, Douglas. 1996. Leadership and collective action: The case of revolution. International Studies Quarterly 40:107-32.

Wagner, R. Harrison. 2000. Bargaining and war. American Journal of Political Science 44:469-84.

Walter, Barbara F. 1997. The critical barrier to civil war settlement. International Organization 51:335-64. 2002. Committing to peace: The successful settlement of civil wars. Princeton, NJ: Princeton University Press.

Werner, Suzanne, and Amy Yuen. 2005. Making and keeping peace. International Organization 59:261-92. Williamson, Owen. 1999. Nicaraguan guerrilla victory. Military History, August. 